Works of the Faculty of Forestry

University of Sarajevo

No. 2, 2017 (1-18)

UDK 639.11:630*45(Kanton Sarajevo)

639.11:630*45(Srednjobosanski kanton)

\title{
GAME DAMAGES IN CANTON SARAJEVO AND CENTRAL BOSNIA CANTON
}

Štete od divljači na području kantona Sarajevo i Srednjobosanskog kantona

Saša Kunovac ${ }^{1}$, Mustafa Bašić ${ }^{2}$, Kemal Starogorčić ${ }^{3}$, Edin Šatrović ${ }^{4}$

\begin{abstract}
:
Human - wildlife conflicts have a long history. Due to continuous growth of the human population, demands for an increase of arable land, raw materials production and living space, man and game were and are direct competitors for space and resources worldwide. Conflicts between humans and game can occur for many reasons, but one of the main causes are certainly damage by game occurs at crops, orchards, livestock, beehives and other forms of human assets. According to previous researches in Europe, most damage is caused by wild ungulates, esspecially wild boar (Sus scrofa L.) and red deer (Cervus elaphus L.) (GORYNSKA, 1981; CSANYI and LEHOCZKI 2010; COZZI et al 2015). Damages can reach significant values, in France more than 8 million $€$ in 2004/2005 (MAiLLARD et al 2010); 12 million $€$ in 2010 in Poland (FRACKOWIAK et al 2013), and 8-10 million $€$ per year in Hungary in the last decade (CSANYI et al 2014). In Croatia, during four years, average annual payment amount was 559,977.49 €(NOVOSEL et al 2012).

In this paper, we determined causes, collected and analyzed data on the reported claims of game damages from two cantons in the Federation of Bosnia and Herzegovina in the period of five years. All damages are sorted by category, cause and by year. We also discussed the legal obligations in terms of damage prevention, notification, claim and assessment of damage, as well as the economic effects of damage in Canton Sarajevo and Central Bosnia Canton.
\end{abstract}

Key words: game, damage, legislation

\section{INTRODUCTION - Uvod}

Prevention and refunding of game damages in $20^{\text {th }}$ century in Bosnia and Herzegovina, according to previous Law on Hunting was regulated only in case of Brown bear (Ursus arctos L) (Rapaić, 1991). With new Law on hunting (2006), some game species changed their former status from "unprotected" to "protected with closed season". Wolf (Canis lupus L.), and Wild boar (Sus scrofa L.) are among these

\footnotetext{
${ }^{1}$ Faculty of Forestry, University of Sarajevo, Bosnia and Herzegovina

${ }^{2}$ Cantonal Forestry Office, Travnik, Central Bosnia Canton, Bosnia and Herzegovina

${ }^{3}$ Ministry of Economy, Forestry department, Canton Sarajevo, Bosnia and Herzegovina

${ }^{4}$ Veterinary faculty, Univeristy of Sarajevo, Bosnia and Herzegovina
} 
species (Kunovac and Avdibegović 2008). According to Law on Hunting of Federation of $\mathrm{BiH}$, game damages are regulated by chapter VIII of this Law, in articles 68-74 is written: „For damage that is done by game species, Game manager takes full responsibility, if the person who claimed damage took prescribed preventive measures. Those measures are prescribed by cantonal rule books about Preventing and refunding game damages. Under protection measure its understood fences (electrical and mechanical), guard dogs, sheppard, and various repellents.

Apart from this, in case of damage caused by Brown bear (Ursus arctos L.) in so-called „Bear breeding areas“, Federation of $\mathrm{BiH}$ refunds $45 \%$, Cantons $25 \%$ and Game managers $30 \%$ of damage.

For game under strict protection (no season), damage is refunded by responsible authority which established protection, in this case Federation of $\mathrm{BiH}$. For non-game species, such as stray dogs, damage is not refunded.

Damage claim is reported to Cantonal ministry in charge (Ministry of Agriculture, Forestry and Water management or Ministry of Economy) at the same day when damage occurs or within three days from moment of damage. Cantonal ministry is obligated to form a Commission ${ }^{1}$ for determining cause and damage assessment, immediately or within 3 days. Commission has three members: represent of Ministry (President of Commission), expert for damage assessment (agricultural or veterinarian) and expert for determining cause of damage (wildlife expert).

Commission is obligated to make an inquiry and protocol as well. At inquiry, Commission calls local Game manager and person who reported damage.

After judgement about cause and value of damage, all present persons are obligated to sign a protocol. Protocol contains: time and place of damage occurrence, tracks and signs which indicate certain game species as well as preventive measures taken. Protocol is further send to Cantonal ministry who determines value of compensation and time limit in which damage has to be refunded.

\section{MATHERIAL AND METHODS - Materijal i metode}

Research considering value, causes, intensity and economical effects of game damages has been conducted in Federation of $\mathrm{BiH}$, at territory of two cantons: Canton Sarajevo and Central Bosnia canton. Canton Sarajevo has a total surface of 1276,9 $\mathrm{km}^{2}$, and Central Bosnia canton comprises $3189,0 \mathrm{~km}^{2}$. According to Regionization and categorization of hunting grounds in Federation of BiH (KUNOVAC et al 2009), both cantons mostly belongs to category of hilly hunting grounds $(55 \%$ and $59 \%$ of terrain is in high span of 400-1000 m.a.s.1.), and in some smaller percent to category of mountainous hunting grounds ( 45 and $40 \%$ of terrain is above 1000 m.a.s.1.). Both cantons are pronouncedly under forests $(55 \%$ i $60 \%$ of total surface is under forests). Arable land with different crops and orchards comprises $18 \%$ of total surface in Canton Sarajevo, or 19\% of total surface in Central Bosnia canton.

\footnotetext{
${ }^{1}$ Authors are members of such Commissions-wildlife experts and damage assessment expert.
} 
These conditions, considering game species are most appropriate for big game species such as Brown bear (Ursus arctos L.), Wild boar (Sus scrofa L.), Wolf (Canis lupus L.), Roe deer (Capreolus capreolus L.) and Chamois (Rupicapra rupicapra balcanica Bolkay). Both cantons are placed within „Bear breeding areas“, established by Federal Ministry of Agriculture, water management and Forestry (Official gazette of Federation of $\mathrm{BiH}$, No 63/08). Canton Sarajevo is placed within bear breeding area „Bjelašnica-Čvrsnica“, and Central Bosnia canton comprises two bear breeding areas: „Plješevica-Vitorog“" and „Vlašić-Vranica“.

In five year period (2010 to 2014), we determined causes of damage (game species or other) according to ČEOVIĆ (1964), and KACZENSKY et al (2008), for all damage claims at Canton Sarajevo and Central Bosnia canton, during 2010-2014. Claims were sorted by realised (refunded) and denied, according to years and in total within research period. Especially, we analysed reasons for denying claims. Furthermore, we analysed damage categories (cattle and horses, sheep and goats, crops, beehives, trees in orchards, and other) as well. Considering economic effects of damages we collected all officially refunded damages in $€$. All data were processed in Microsoft Excel and presented graphically for both cantons and in total.

\section{RESULTS - Rezultati}

In period from 2010 to 2014 year, for both cantons, total of 461 damage claims were reported. In canton Sarajevo we had 194 claims and 267 claims in Central Bosnia canton. Number of claims by year and in total is presented at Figure 1.

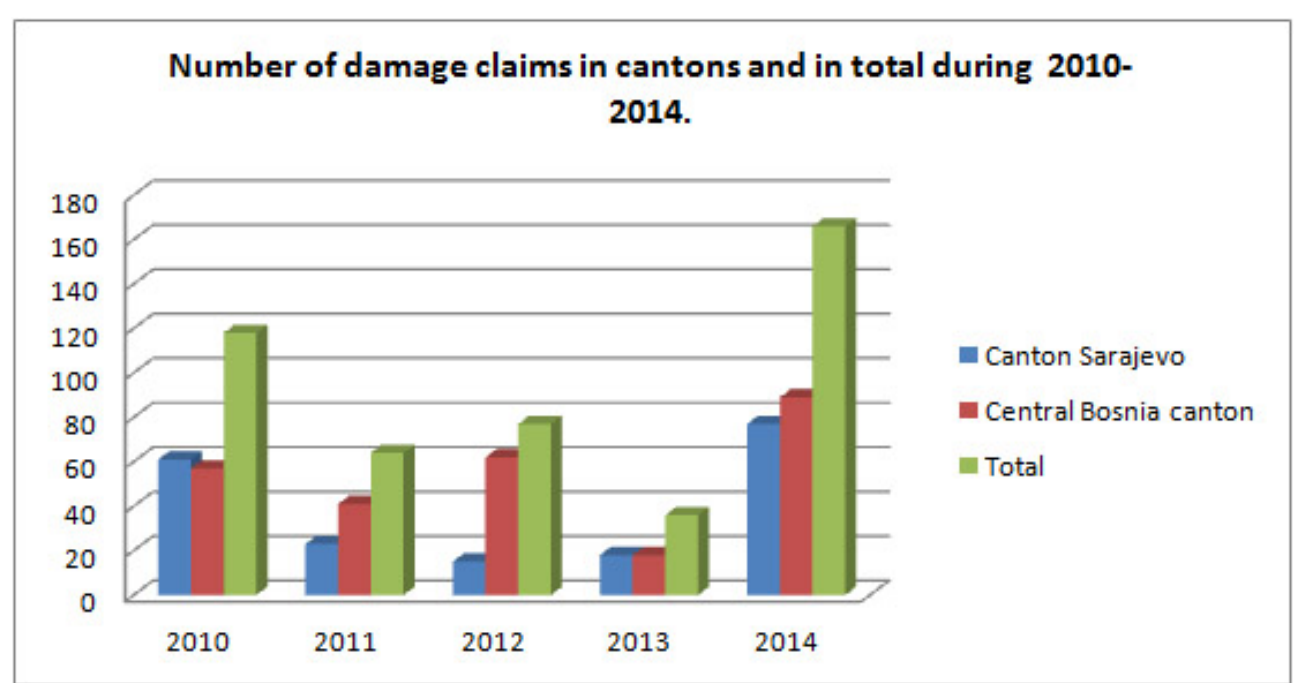

Figure 1. Damage claims in 2010-2014 period.

Slika 1. Zahtjevi za nadoknadu štete u periodu 2010-2014. 
From figure 1 we see that in both cantons most of damage claims were reported in $2014(n=166)$, and the smallest number of claims were reported in 2013 $(n=36)$. In Canton Sarajevo, the biggest number of claims $(n=77)$ were in 2014 and the smallest in $2012(\mathrm{n}=15)$. Central Bosnia canton has also the biggest number of claims in $2014(\mathrm{n}=89)$, and the smallest $(\mathrm{n}=18)$ in 2013. Average number of damage claims by year is 39 in Canton Sarajevo, and 53 in Central Bosnia canton. In both cantons, we have average of 92 damage claims per year.

Number of realised and denied claims in each canton is presented at figures 2 and 3 .

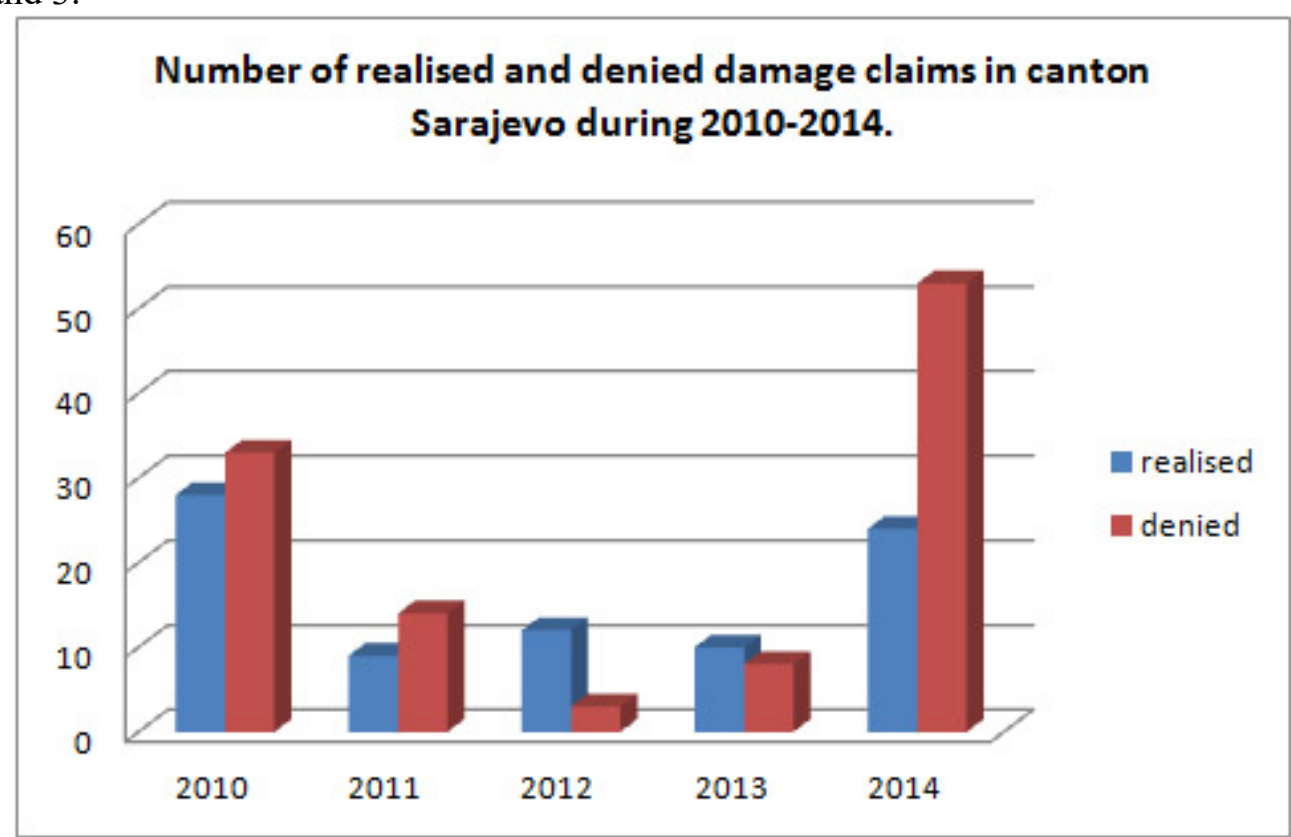

Figure 2: Realised and denied damage claims in canton Sarajevo during 2010-2014.

Slika 2. Realizovani i odbijeni zahtjevi u kantonu Sarajevo za period 2010-2014. 


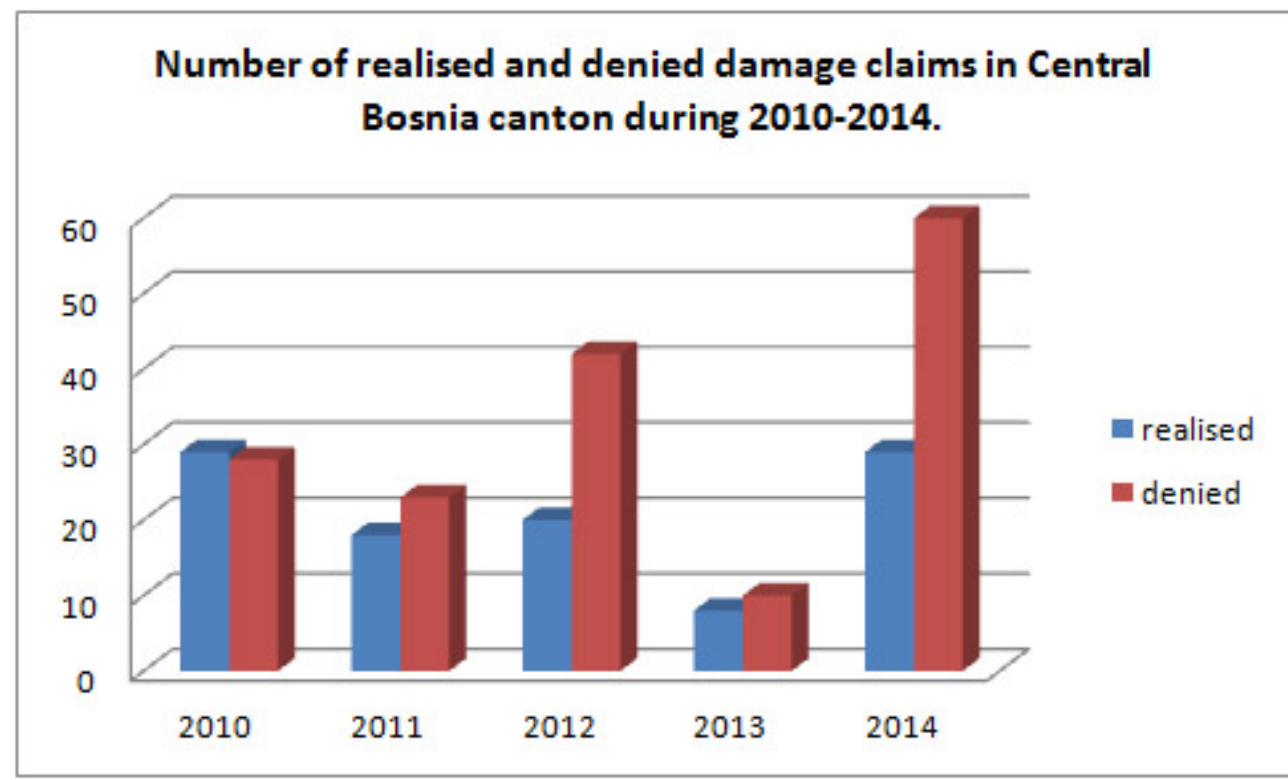

Figure 3. Realised and denied claims in Central Bosnia canton during 2010-2014. Slika 3. Realizovani i odbijeni zahtjevi u Srednjobosanskom kantonu za period 2010-2014.

Total ratio of realised and denied damage claims is shown at figure 4.

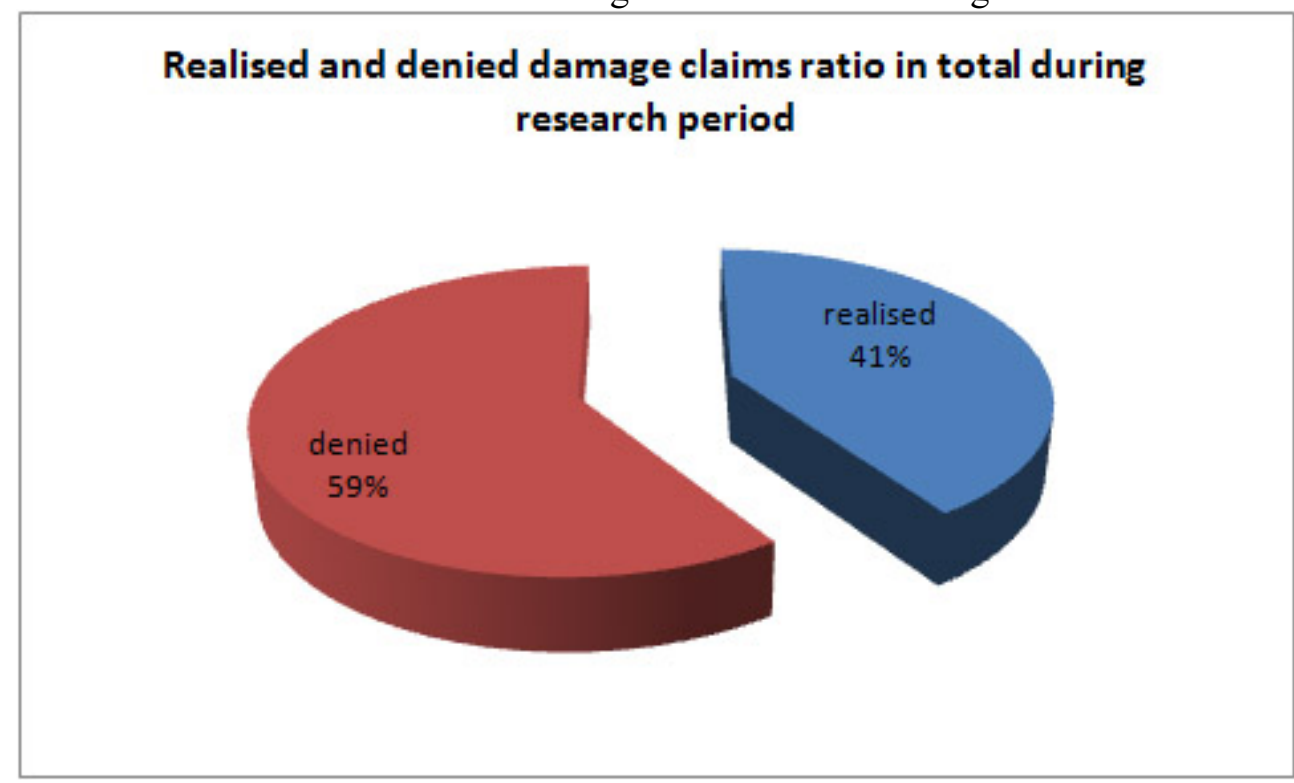

Figure 4. Realised and denied claims ratio in total Slika 4: Odnos realizovanih i odbijenih zahtjeva 
As it shown at figures 2, 3 and 4, from 461 reported damage claims during five years in both cantons, we have 187 realised and 274 denied claims. Total percent of realised claims is $41 \%$. In Canton Sarajevo, we have 83 realised claims versus 111 denied, or $43 \%$ of all claims $(n=194)$ are realised. In Central Bosnia canton, percent of realised claims in somewhat lower and it is $43 \%$, or 104 realised and 163 denied claims from total of 267 claims in this canton during five years.

Analysed reasons for denying claims (no refund) were processed together for both cantons. Reasons for denying claims are in most of cases lack of appropriate fence, recorded in 53 cases of $33 \%$. At second place is lack of guard dogs in 52 cases or $32 \%$, and absence of sheppard in third place, recorded in 42 cases or $25 \%$. Attempts of rigging damage were recorded in 8 cases or $5 \%$, untimely claim in 6 cases or $4 \%$, and all other causes for denying claim were recorded in just one case. Percent ratio of reasons for denying damage is presented at figure 5 .

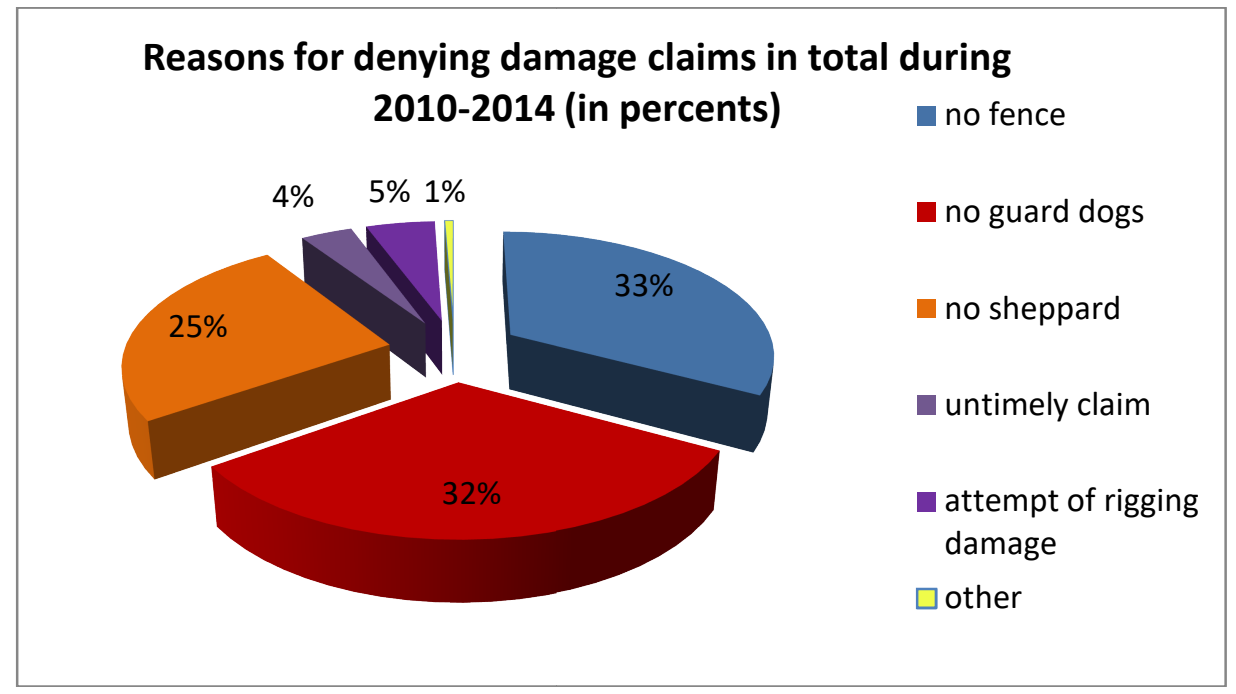

Figure 5: Reasons for denying damage claims in percents, during 2010-2014.

Slika 5. Procentalna zastupljenost razloga za odbijanje zahtjeva u periodu 2010-2014.

Review of damage causes is presented by cantons and years as well as in percent ratio in total at figures 6,7 and 8: 


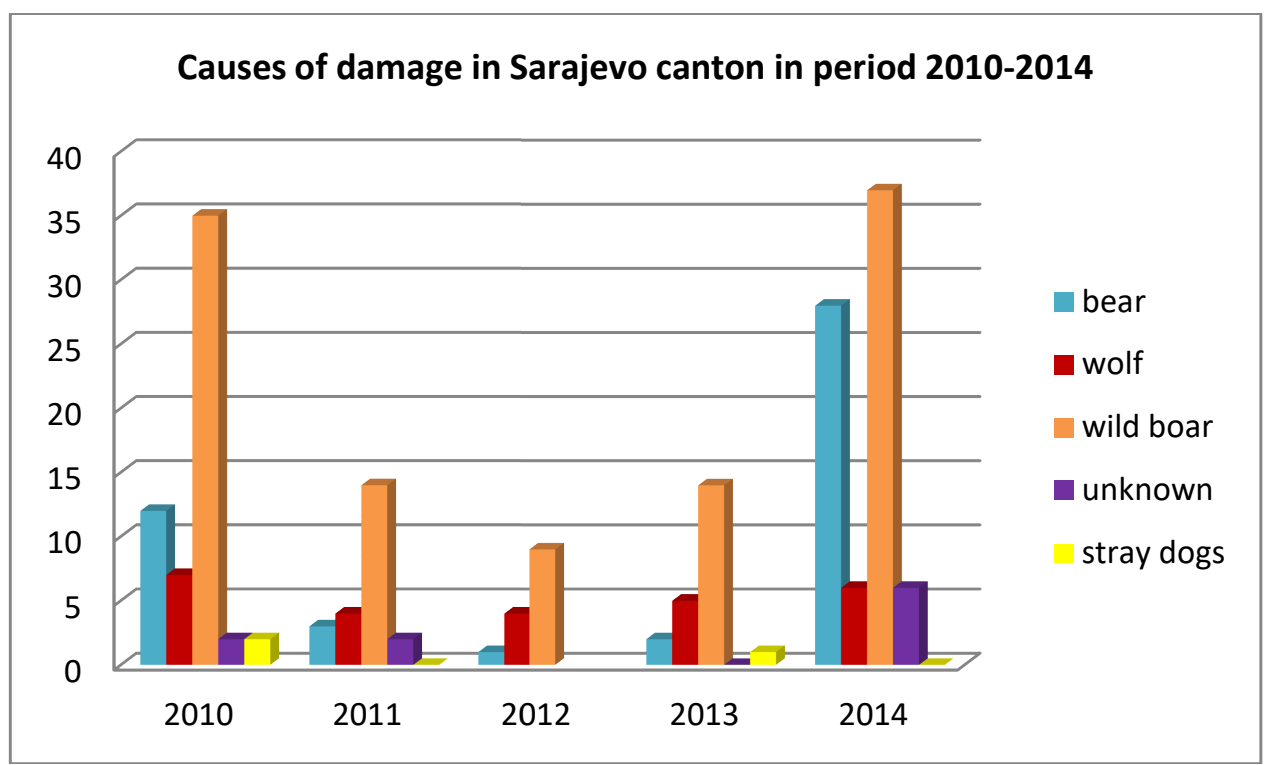

Figure 6. Causes of damage in Sarajevo canton during 2010-2014.

Slika 6. Uzročnici šteta u kantonu Sarajevo u periodu 2010-2014

From Figure 6, we see that the most common cause of damage in Canton Sarajevo is Wild boar in all five years and in total. After boar come Brown bear and wolf, then stray dogs and in four cases it was not possible to determine cause of damage.

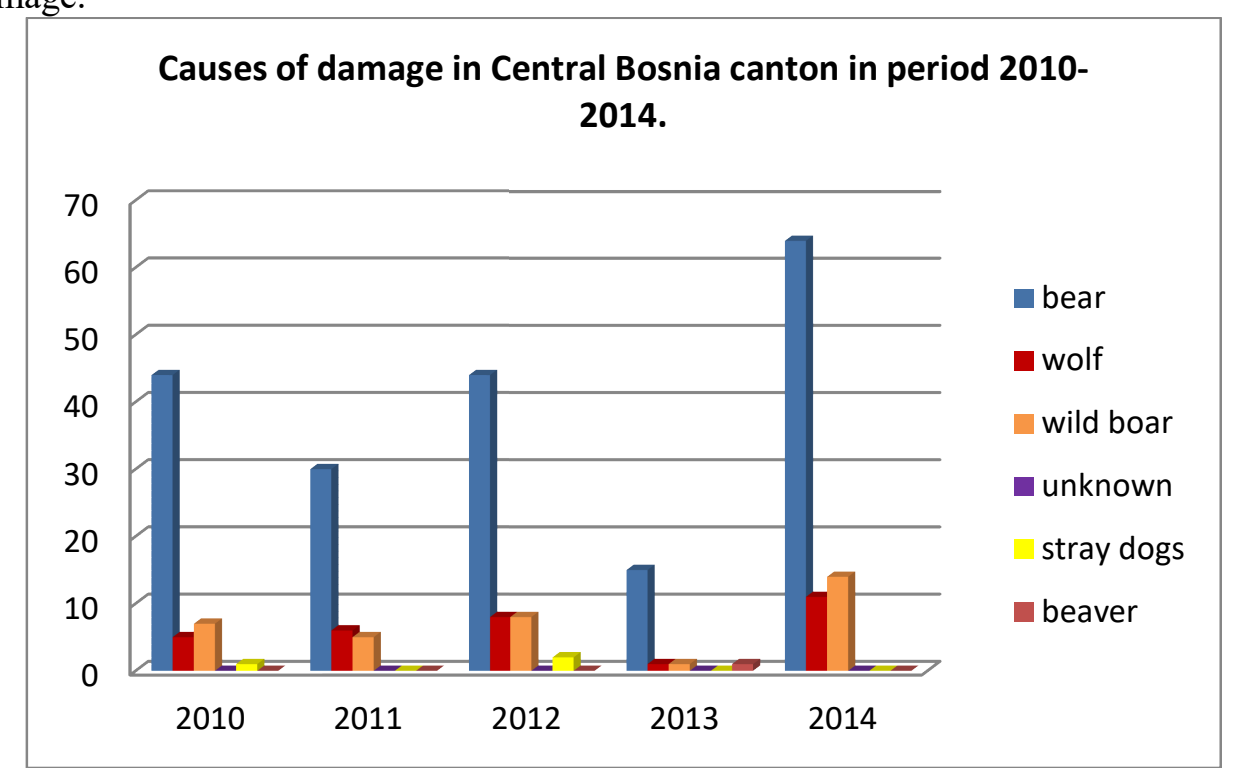

Figure 7. Causes of damage in Central Bosnia canton during 2010-2014.

Slika 7. Uzročnici šteta u Srednjobosanskom kantonu u periodu 2010-2014. 
In Central Bosnia canton, most common cause of damage is Brown bear, per years and in total. Wolf and Wild boar are almost equally represented (21 and 20 cases), stray dogs were responsible for damage in three cases, and European beaver (Castor fiber) is at the last place or in just one case. In Central Bosnia canton, we didn't record a case in which damage cause could not be determined.

\section{Percent ratio of damage causes in both cantons during}

2010-2014.

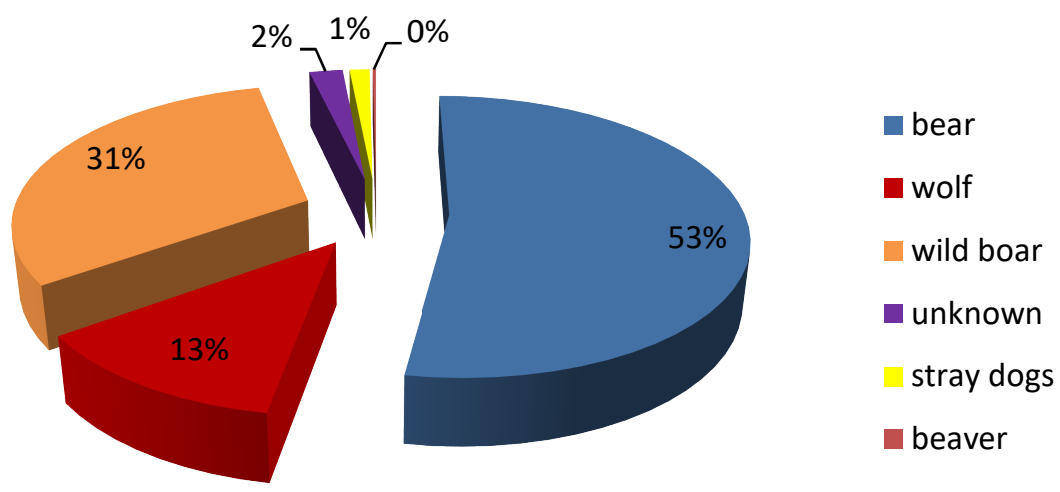

Figure 8. Percent ratio of damage causes in both cantons during 2010-2014

Slika 8. Procentualna zastupljenost uzročnika šteta u oba kantona tokom 2010-2014.

Figure 8 shows percentage ratio of damage causes in both cantons during research period. We see that in total, more than half of all reported damages were committed by Brown bear, recorded in 147 cases or 53\% during 2010-2014. In average, we have 29,4 cases of damage caused by bear, yearly. SINDIČIĆ et al (2011), reported 37,8 cases yearly, but in whole Croatia. Wild boar is at second place with 93 recorded cases, wolf with 36 cases, stray dogs in 6 cases and European beaver in one case.

We classified all damages within usual categories: cattle and horses, sheep and goats, beehives, orchards (number of damaged trees), crops (in hectares) and all other types of damage in category „other". Damage by categories, for both cantons and in total are presented at figures 9,10 and 11 . 


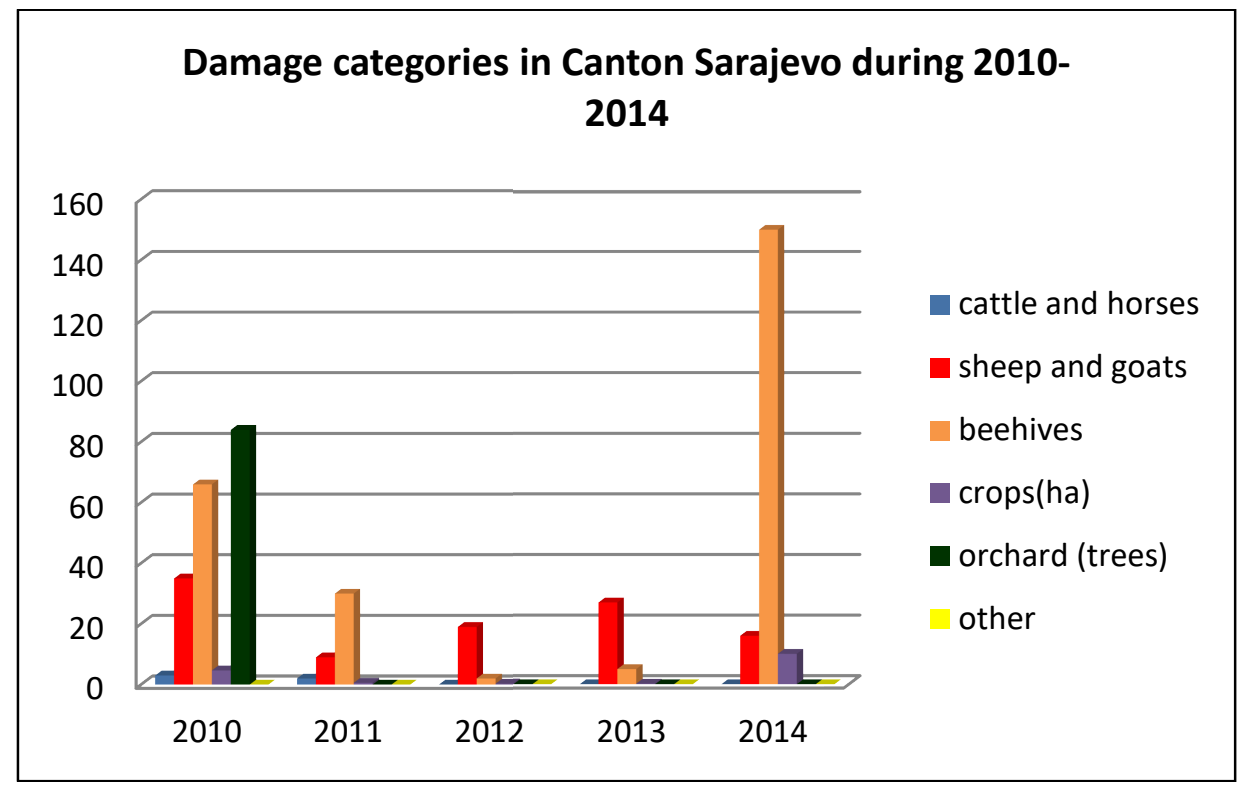

Figure 9. Damage categories in Sarajevo canton during 2010-2014. Slika 9. Kategorije šteta u kantonu Sarajevo u period 2010-2014.

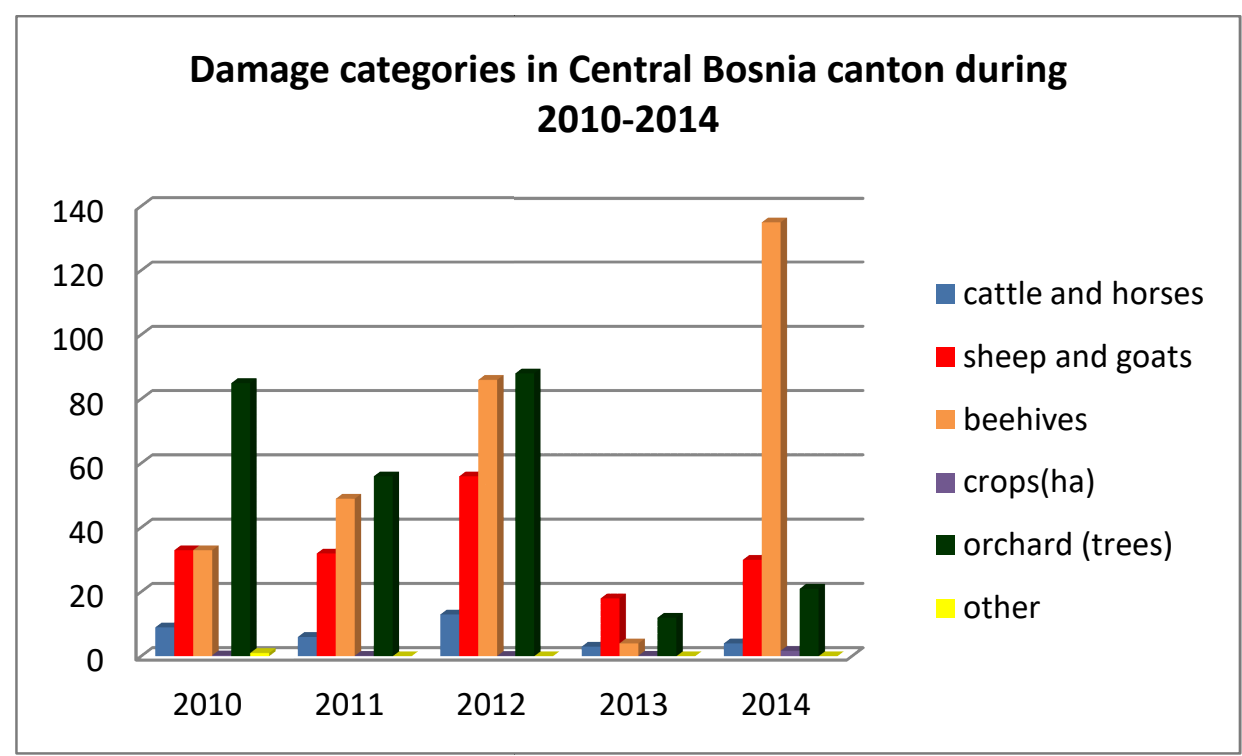

Figure 10. Damage categories in Sarajevo canton during 2010-2014. Slika 10. Kategorije šteta u kantonu Sarajevo u periodu 2010-2014. 


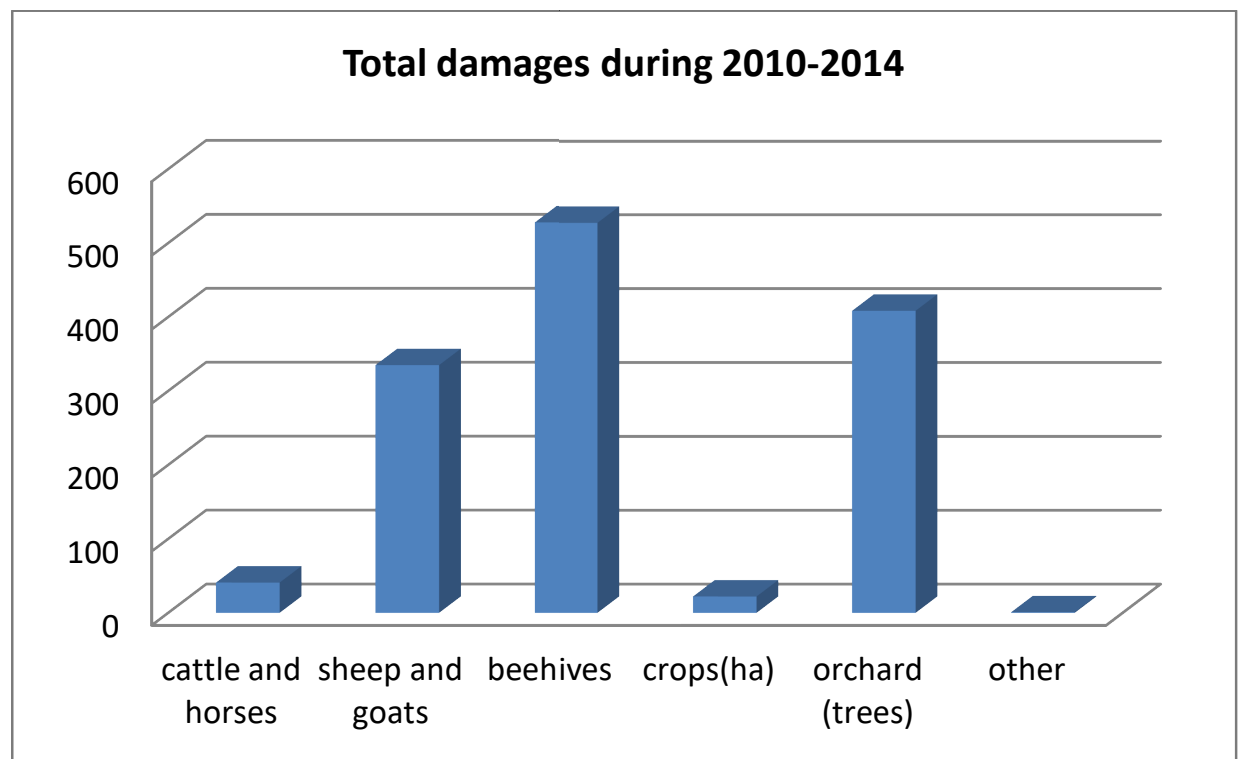

Figure 11. Total damages according categories during 2010-2014.

Slika 11: Ukupne štete po kategorijama u periodu 2010-2014.

From Figures 9, 10 and 11, we understand that beehives and trees in orchard are most represented damage category, followed by sheep and goats, cattle and horses, in both cantons and in total. Least damages were recorded at crops. Within these five years (Figure 11) we recorded damage at 409 trees in orchards, 528 beehives, 335 heads of sheep and goats, 41 heads of cattle and horses, 22,23 hectares of crops (wheat, maize, potato), as well as one sheppard dog (killed by bear in Central Bosnia canton) which is classified in „other" category.

Based on this data, we can see that average yearly damage, according categories is 106 beehives, 82 trees in orchards, 67 sheep and goats, 8 cattle and horses and 4,46 hectares under crops.

Economic values of damages are presented in Euro. We considered only refunded amounts, according to decisions of Commission for damage assessment. Damage values per year and in total, for both cantons are presented at figure 12: 


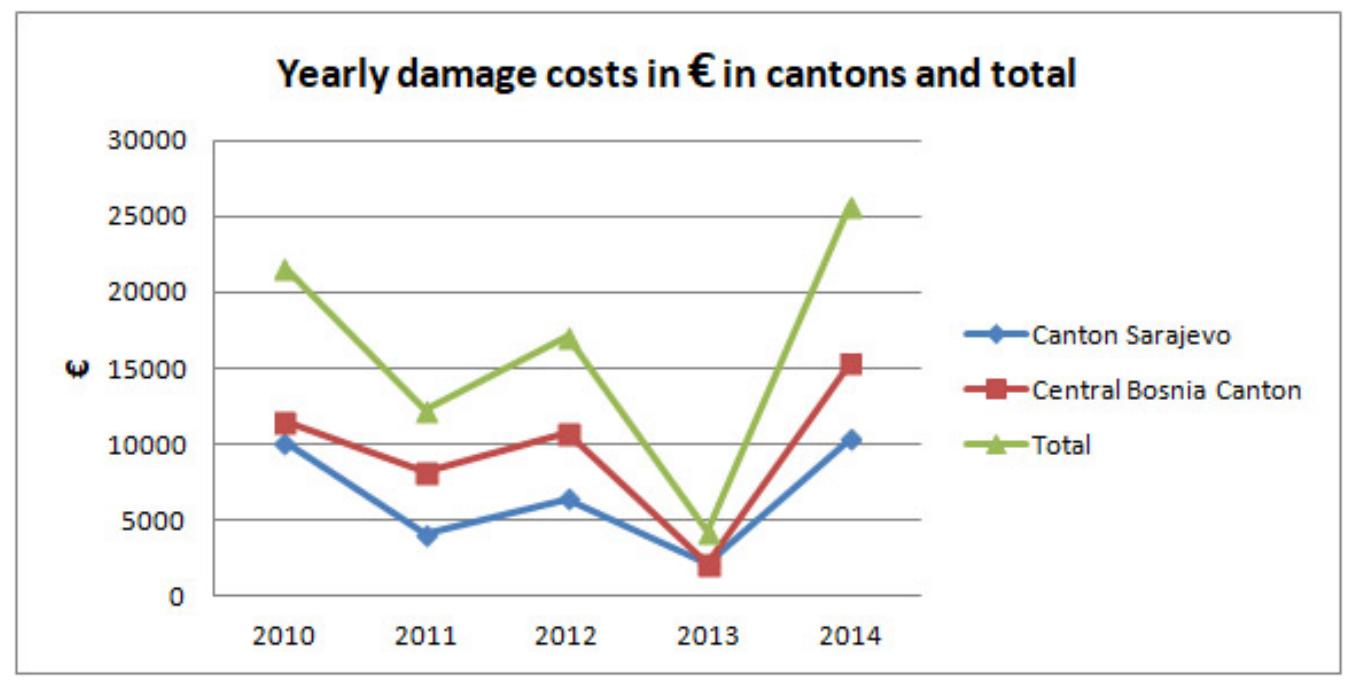

Figure 12. Yearly damage costs in cantons and total.

Slika 12: Godišnja visina šteta po kantonima i ukupno.

From Figure 12 we can see that total damages were highest in 2014 year (more than $25.000 €$ ) as well as that year recorded highest damages in both cantons separately. Lowest damages were recorded in 2013, which is also a year with smallest number of damage claims.

Total value of all damages within five year period is 80936,65 €, in Canton Sarajevo this value is $33.156,00 €$, and $47.780,65 €$ in Central Bosnia canton.

Average yearly value of total damages for analyzed period (2010-2014) is $16.187,33 €$, in Canton Sarajevo average yearly value is $6.631,20 €$, and $9.556,13 €$ in Central Bosnia canton. Average compensation amount per single damage is $432,81 €$.

\section{DISCUSSION - Diskusija}

In Canton Sarajevo we have tendency of decreasing damage claims after 2010 till strong increase in 2014. In Central Bosnia canton we recorded variations from year to year. These differences between cantons can be explained by fact that in Canton Sarajevo we have eight established hunting grounds, from 2010, which are managed by hunting clubs. According to legislation, game managers (Hunting clubs) are obligated to take measures in order to prevent game damages. Some of these measures include education and information of local people about their obligations and duties considering game damages as well as to maintain game populations at level of carrying capacity. This was obviously performed in Canton Sarajevo and had positive impact at number of damages in further three years.

In Central Bosnia canton we have completely different situation. Authorities in charge didn't finished process of establishing and renting hunting grounds. In such a 
situation often we have two, three or even more hunting clubs who claims same area as „their" hunting ground. Cantonal Ministry of agriculture, water management and forestry, gives yearly temporary approval to these hunting clubs to manage and hunt in same area. Those decisions have a serious consequences considering game management, hunting quotas, and lack of all necessary measures considering prevention of game damages.

We isolate 2014 years from analysis above, considering the fact that this year was extremely inconvenient for wildlife, with floods and harsh weather conditions (cold and almost constant precipitations) all year round. Lack of natural food resources in this year, drive wildlife to search for any available food source, which results in highest damages and largest number of claims in analysed period (UROŠEVIĆ et al 2017).

On the contrary, in 2013 we had full fructification of beech and oak mast as well as all other tree species and forest fruits. Generally speaking 2013 year was one of richest years in last few decades, which had positive impact at number of damages.

Differences in yearly average number of damage claims in favour of Central Bosnia canton (39:53) can be explained by far more (almost double) territory size of Central Bosnia canton than Canton Sarajevo $\left(1276,9 \mathrm{~km}^{2}: 3189,0 \mathrm{~km}^{2}\right)$.

Total number of denied damage claims within five year period was 274 or $59 \%$ of all claims, as well as most common reasons for denying claims (lack of fences, guard dogs or sheppard) which comprises $90 \%$ of all reasons for denying claims, point to very poor legislation knowledge considering obligations and duties of stakeholders in damage prevention and refunding, at local people.

If we analyse these data by cantons, we can see that in Canton Sarajevo we have lower percent of denied claims than in Central Bosnia canton $(57 \%: 61 \%)$. This also goes in favour of previously mentioned fact about information and education of local people which game managers performed in Canton Sarajevo.

Considering damage causes (Figure 8), in total, most common cause is brown bear (243 of 461 cases or 53\%) apart from findings in Europe (GORYNSKA, 1981; CSANYI and LEHOCZKI 2010; COZZI et al 2015). Wild boar is responsible for one third of all damages (144 cases or 31\%), wolf caused damage in 57 cases or $13 \%$, stray dogs take part with $2 \%$ of total damages as well as undetermined causes $2 \%$.

Quite high presence of brown bear in damage cause, especially in Central Bosnia canton ( $74 \%$ of all damages in this canton), is more-less expected, because both cantons are within so-called ,bear breeding areas", and bear habitats in Central Bosnia canton are considered as some of highest quality habitats for this species. Beside this, as a consequence of non-establishing of hunting ground and poor management in Central Bosnia canton, regular bear feeding (provided by game managers) occurs only occasionally, in opposite to situation in Canton Sarajevo. Wild boar and wolf share the second place with $13 \%$ and $12 \%$ responsibility of all damages in Central Bosnia canton, while all other damage causes (stray dogs, beaver) take part with only $1 \%$. 
Wild boar is most common damage cause in Canton Sarajevo with $56 \%$ of all damages in this canton during five years. Bear is responsible for one quarter of damages in this canton with $24 \%$, stray dogs with $2 \%$ and undetermined causes with $5 \%$.

When we look at damage categories in total (Figure 11), we see that damage at beehives and trees in orchards are most common. In both cantons we have tradition of moving beehives according to time of year and vegetation growth. Generally, after setting beehives into position somewhere in mountains, people leave it without any supervision, or only with poor constructed fences which are no serious obstacle for bear. In Croatia, beehives comprimes only $8,8 \%$ of all damages caused by bear (SINDIČIĆ et al 2011). Considering trees in orchards, we have a similar situation, cause in both cantons we have prevailing extensive fruit-growing. This means that we have numerous small orchards near villages (in nowadays situations visited only during summer), with traditional wooden fences or no fence at all. This can be considered as direct cause for high damages in those two categories.

In third category, we have sheep and goats. Nomadic herding of sheep and goats is also very traditional in both cantons. Unfortunately it does not understand quality fences or quality guard dogs (able to confront with wolf or bear), so as well as local people, sheppard need proper information and education too.

Cattle and horses are in fourth place according to representation in total damages. As sheep and goats, they are more than often left at pastures, especially during summer times.

Crops are fenced in most of cases, nowadays with electric fence in most of cases, so damages in this category are not high and occur only in distant areas (lonely villages or estates).

Damage values maybe not seems so high, but considering life standard in Federation of $\mathrm{BiH}$ and ability of game managers to refund damage, beside other obligations (rent for hunting ground, game wardens etc), they represent a serious problem and obstacle in regular game management as well for local farmers and shepherds. Rapaić (1991), presented data for brown bear damages in $\mathrm{BiH}$ during twelwe year's period (1977-1988). According to this, average number of realised claims was 1068 per year, average compensation amount per single damage was $150,00 €$, and average yearly amount of damage was $161.102 €$. We can see that nowadays, compensation amount per single damage is almost three times higher than in $20^{\text {th }}$ century, despite huge difference in average number of realised damage claims per year $(37,4: 1068)$ and in average total damage per year $(16.187,33 €: 161.102 €)$.

Quite slow process of determining damage and waiting for refund causes tensions between game manager and local people. This often led into increasing poaching, especially in case of denying damage. Fact that a few sheep, cow, beehives or something else represent only possible yearly income for local people, causes a strong reactions in case of denied damage claim. It's not rare that in repeatedly denied damage claim, people use poison, various traps and even electric power to exterminate 
game from its properties. Such activities create new conflicts between authorities, game managers and local people.

\section{CONCLUSIONS - Zaključci}

Based on results of research considering value, causes, intensity and economical effects of game damages during five years in two cantons of Federation $\mathrm{BiH}$, we can conclude as follows:

- There is a very poor knowledge about current legislation and obligations of stakeholders in terms of damage prevention, notification, claim and assessment of damage;

- Authorities in charge and game managers have to take a greater efforts considering information and education of stakeholders in order to decrease game damages, especially in Central Bosnia canton;

- Extent of game damages can be influenced by weather conditions as it shown in year 2013 and 2014;

- Most common cause of all damages is brown bear, due to poor protection measures, especially at beehives and orchards. For the same reason, these two categories are most represented in total damage during five years.

- Wild boar and wolf take second place as a most common cause of all damages in both cantons after bear, and in Canton Sarajevo wild boar is primary cause of damages.

- Nomadic herding of livestock needs improvement, especially in supplying shepherds with proper guard dogs;

- Presented damage values are a serious problem both for game managers and stakeholders in nowadays situation and life conditions in Federation of $\mathrm{BiH}$; 


\section{REFERENCES - Literatura:}

BLEIER N., KOVÁCS I., SCHALLY G., SZEMETHY L., CSÁNYI S. (2016): Spatial and temporal characteristics of the damage caused by wild ungulates in maize (Zea mays L.) crops, International Journal of Pest Management, DOI: 10.1080/09670874.2016.1227487

BLEIER N., LEHOCZKI R., ÚJVÁRY D., SZEMETHY L., CSÁNYI S. (2012): Relationships between wild ungulates density and crop damage in Hungary, Acta Theriol (2012) 57:351-359

CALENGE C, MAILLARD D, FOURNIER P, FOUQUE C. (2004): Efficiency of spreading maize in the garrigues to reduce wild boar (Sus scrofa) damage to Mediterranean vineyards, Eur J Wildl Res. 50:112-120.

COZZI M, ROMANO S, VICCARO M, PRETE C, PERSIANI G. (2015): Wildlife agriculture interactions, spatial snalysis and trade-off between environmental sustainability and risk of economic damage In: Vastola A, editor. The sustainability of agro-food and natural resource systems in the Mediterranean Basin. p. 209-224.

CSANYI S, LEHOCZKI R. (2010): Ungulates and their management in Hungary“, In: Apollonio M, Andersen R, Putman R, editors. European ungulates and their management in the 21 st century. Cambridge (UK): Cambridge University Press; p. 291-318.

ČEOVIĆ I. (1964): Tragovi divljači, Panorama, Zagreb, str 1-372.

FRACKOWIAK W, GORCZYCA S, MERTA D, WOJCIUCH-PLOSKONKA M. (2013): Factors affecting the level of damage by wild boar in farmlands in north-eastern Poland. Pest Manag Sci. 69:362-366.

GAČIĆ P.D., DANILOVIĆ M. (2009): Damage caused by red deer (Cervus elaphus) and wild boar (Sus scrofa) in forest hunting grounds in Serbia, Bulletin of the Faculty of Forestry 99: 15-32.

GORYNSKA W. (1981): Method of determining relations between the extent of damage in farm crops, big game numbers, and environmental conditions, Acta Theriol. 26:469-481.

KACZENSKU P., HUBER T., REINHARD I., KLUTH G. (2008): Wer war es?, Wildland-Stiftung Bayern, p.1-56.

KUNOVAC S., AVDIBEGOVIĆ M. (2008): Law on Hunting and it's by laws in the Federation of Bosnia and Herzegovina - a new approach, IUFRO Division 6: Social, Economic, Information and Policy Sciences, Forest Law and Environmental Legislation, International Symposium, Sarajevo, Bosnia and Herzegovina. Proceedings of the $10^{\text {th }}$ International Symposium, pp 35-41.

KUNOVAC S., BAŠIĆ M., SKROBO N., LIČANIN S: (2008): Brown bear (Ursus arctos L.) Damages at forest stands in Central Bosnia Canton, Works of the Faculty of Forestry, University of Sarajevo, No 1 2008, pp 79-90. 
KUNOVAC S., MEKIĆ F., VOJNIKOVIĆ S., AVDIBEGOVIĆ M., LOJO A., HUKIĆ EMIRA (2009): Rejonizacija i kategorizacija lovišta u Federaciji Bosne i Hercegovine, Sumarski fakultet Univerziteta u Sarajevu i Federalno ministarstvo poljoprivrede, vodoprivrede i šumarstva, Sarajevo, Univerzitetski udžbenik, 1126.

NASIADKA, P., JANISZEWSKI, P. (2015): Food preferences of wild boars (Sus scrofa L.) in the summer and early autumn expressed by the damage caused in agricultural crops, Sylwan. 159. 307-317.

NOVOSEL H., PIRIA M., SAFNER R., KUTNJAK H., ŠPREM N. (2012): The game damages on agricultural crops in Croatia, Journal of Central European Agriculture, 2012, 13(4), p.631-642

POPOVIĆ Z. (2006): Štete od divljači na šumskim i poljoprivrednim kulturama, Glasnik Šumarskog fakulteta Univerziteta u Banjoj Luci, br 6., str 51-64.

POPOVIĆ Z., ĐORĐEVIĆ N. (2010): Gazdovanje populacijama divljači u cilju smanjenja šteta, Poljoprivredni fakultet Univerziteta u Beogradu. Beograd, 1-218.

RAPAIĆ Ž. (1991): Zaštita medvjeda, Lovački list, januar-februar 1991, 12-13, Sarajevo.

SCHLEY L, DUFRENE M, KRIER A, FRANTZ AC. (2008): Patterns of crop damage by wild boar (Sus scrofa) in Luxembourg over a 10-year period. Eur J Wildl Res. 54:589- 599 .

SINDIČIĆ M., ZEC, D., HUBER Đ. (2011): Analiza šteta od smeđih medvjeda u Hrvatskoj u razdoblju od 2004. do 2009. godine, Šumarski list br. 1-2, CXXXV (2011), 63-68

MINISTARSTVO POLJOPRIVREDE, VODOPRIVREDE I ŠUMARSTVA SBK/KSB (2010): Pravilnik o sprečavanju i nadoknadi šteta od divljači, Službene Novine SBK/KSB, broj 16/10., Travnik.

MINISTARSTVO PRIVREDE KS (2007): Mjere u cilju sprečavanja šteta od divljači i na divljači, Službene Novine KS, broj 37/10., Sarajevo.

PARLAMENT FBiH (2006): Zakon o Lovstvu Federacije BiH, Službene novine Federacije BiH broj: 04/06; Sarajevo.

PARLAMENT FBiH (2014): Zakon o izmjenama i dopunama Zakona o lovstvu Federacije BiH, Službene novine Federacije BiH broj: 81/14; Sarajevo.

UROŠEVIĆ M., MATARUGIĆ D., DROBNJAK D., ŽIVKOVIĆ B. (2017): Uticaj roda žira na štete od divlje svinje (Sus scrofa) na poljoprivrednim kulturama u Homolju, Ветеринарски журнал Републике Српске - Veterinary Journal of Republic of Srpska 65-68. 


\section{SAŽETAK}

Konflikti između ljudi i životinja stari su koliko i ljudski rod. Zahvaljujući neprestanom rastu ljudske populacije, nastojanjima da se povećaju površine obradivog zemljišta, proizvodnje sirovina i životnog prostora, čovjek i divljač su direktni takmaci za resurse i prostor širom svijeta. Ovi konfilkti nastaju iz brojnih razloga, a jedan od najvažnijih su štete koje divljač čini na usjevima, voćnjacima, stoci i drugim vrstama čovjekove imovine.

Prevencija i regulisanje šteta od divljači u Bosni i Hercegovini do devedesetih godina prošlog vijeka odnosila se samo na medvjeda, dok se za štete počinjene od drugih životinjskih vrsta nije isplaćivala nadoknada. (KUNOVAC and AVDIBEGOVIĆ 2008). Novim Zakonom o lovstvu (2006), status lovostajem zaštićenih vrsta divljači stekle su i neke druge vrste divljači, koje pričinjavaju znatne štete čovjekovoj imovini, prije svega vuk i divlja svinja (KUNOVAC and AVDIBEGOVIĆ 2008).

Istraživanje o visini, uzročnicima, intenzitetu i ekonomskim efektima šteta od divljači provedeno je na području Federacije $\mathrm{BiH}$, odnosno u Kantonu Sarajevo i Srednjobosanskom kantonu.

U periodu od 2010 - 2014 godine, kao članovi Komisija za utvrđivanje uzroka štete, direktno smo utvrdili uzroke šteta, a potom analizirali sve podnesene zahtjeve za nadoknadu šteta na području Kantona Sarajevo i Srednjobosanskog kantona. Zahtjeve smo razvrstali prema realizovanim i odbijenim, po godinama i sveukupno $u$ istraživanom periodu. Posebno su obrađeni razlozi za odbijanje zahtjeva za nadoknadu šteta. Potom smo pristupili analiziranju direktno utvrđenih uzročnika šteta, odnosno vrste divljači koja je pričinila štetu Vrste šteta su prikazane po kategorijama (krupna stoka, sitna stoka, usjevi, pčelinja društva, voćnjaci i ostalo). Što se tiče ekonomske vrijednosti šteta, prikupljeni su podaci o isplaćenim iznosima za nadoknadu šteta u konvertibilnim markama, te su konvertovani u odgovarajuće iznose u Eurima prema važećoj kursnoj listi.

Rezultati istraživanja pokazuju da je od ukupno 461 zahtjeva za nadoknadu šteta, 187 realizovano a 274 odbijeno, što ukazuje na vrlo slabo poznavanje i informisanost $u$ pogledu načina prijave štete, kao i mjera koje su vlasnici dobara dužni preduzeti da do štete ne dođe. Prosječan broj zahtjeva godišnje je 92 na oba kantona ukupno. Godine sa najmanjim i najvećim brojem zahtjeva za nadoknadu štete su 2013 i 2014, a na ovakvo stanje umnogome su uticale i vremenske prilike tokom ove dvije godine. U pogledu razloga za odbijanje zahtjeva, preko $90 \%$ čine odsustvo pastira, nedostatak odgovarajuće ograde ili psa čuvara.

Kada su u pitanju uzročnici šteta, u oba kantona, sa slike 8 vidimo da preko polovina svih pričinjenih šteta otpada na medvjeda (243 od 461 slučajeva ili 53\%), divlja svinja je uzročnik jedne trećine svih pričinjenih šteta (144 slučaja ili 31\%), vuk je uzročnik štete u 57 slučajeva ili $13 \%$, dok na pse lutalice otpada $2 \%$ pričinjenih šteta, odnosno 6 slučajeva, a uzrok štete nije utvrđen u ukupno 10 slučaja ili $2 \%$. Veoma izraženo učešće medvjeda u ukupnim štetama, posebno u Srednjobosanskom kantonu (74\% svih pričinjenih šteta), ne čudi, s obzirom da se oba područja nalaze unutar uzgojnih 
područja za medvjeda u Federaciji BiH, a staništa medvjeda unutar Srednjobosanskog kantona su najkvalitetnija u cijeloj Bosni i Hercegovini. Najzastupljenije štete po kategorijama su pčelinjaci i stabla u voćnjacima. Pčelinjaci se na području oba kantona tokom godine često dislociraju, u skladu sa promjenama u vegetaciji, odnosno pčelinjaci se odvoze na „pašu“ i u pravilu, ostavljaju bez nadzora, obezbijeđeni opet $u$ najbolje samo iznimno mehaničkim ogradama koje ne predstavljaju ozbiljniju prepreku za medvjeda. U oba kantona preovladava tradicionalno ekstenzivno voćarstvo, te su iz tog razloga voćnjaci u najboljem slučaju obezbijeđeni samo tradicionalnim drvenim ogradama ili bez ikakvih ograda u najvećem broju slučajeva, a samim tim su i pretpostavke za nastanak šteta veće. Ovo je direktni uzrok najčešćih šteta u ove dvije kategorije.

Ukupna vrijednost svih pričinjenih šteta $u$ istraživanom periodu je 80.936,65 $€$, ukupna vrijednost svih šteta u kantonu Sarajevo je 33.156,00 €, a ukupna vrijednost svih šteta u Srednjobosanskom kantonu tokom pet godina je 47.780,65 €. Ukupna prosječna vrijednost godišnjih šteta u periodu 2010-2014 godina iznosi 16.187,33 €, prosječna vrijednost godišnjih šteta $u$ kantonu Sarajevo je 6.631,20 Euro, a u Srednjobosanskom kantonu 9.556,13 €. Prosječna nadoknada po pojedinačnoj šteti tokom analiziranog perioda iznosi $432,81 €$.

Corresponding author: Saša Kunovac; Faculty of Forestry University Sarajevo; Zagrebačka 20, 71000 Sarajevo, Bosna\&Herzegovina; e-mail address: s.kunovac@sfsa.unsa.ba 